\title{
Polonium-210 mordet
}

\section{Thomas Bindesbøll Larsen}

\section{Giftmord er på ny blevet en makaber politisk reali- tet. Hvad er perspektiverne efter det radioaktive mord på en politisk afhopper fra Rusland, der blev myrdet på britisk territorium, just som han var blevet britisk statsborger?}

Da Aleksandr Litvinenko (AL) om aftenen den 23. november 2006 døde på et hospital i London, fik England sit første 'radioaktive terrormord' nogensinde.

Men det er kun ved et rent tilfælde, at ordet radioaktiv er blevet en del af rubriceringen; kun takket være Litvinenkos meget stærke fysik og en snarrådig læges beslutning om et sidste desperat diagnose-tjek af den døende mands urin blev det opdaget, at et radioaktivt alfa-stråleisotop, polonium 210 (po-210) var årsagen til hans pinefulde $\mathrm{d} ø \mathrm{~d}$.

Denne opdagelse blev helt central. Ikke blot for at stille diagnosen og fastslå den eksakte dødsårsag, men også for politiefterforskningen og for de mange spekulationer om motiverne til giftmordet og de mulige bagmænd. Hvis den helt specifikke test for po-210 ikke var blevet gen- nemført, eller hvis Litvinenkos hjerte eller andre livsvigtige organer havde sagt stop allerede få dage efter forgiftningen den 1 . november 2006, ville det engelske politi have været efterladt med en mystisk dødelig forgiftning. Uden tekniske beviser og uden muligheder for sporing. $\mathrm{Nu}$ skulle netop den målrettede sporing af po-210 få dramatiske konsekvenser for politiefterforskningens resultater.

Ruslands præsident, Vladimir $\mathrm{Pu}$ tin, udtalte kort efter giftmordet på EU-topmødet i Helsingfors, at de engelske myndigheder, så vidt han havde fået oplyst, ikke rubricerede Litvinenkos død som en forbrydelse. Det var en sandhed med modifikationer. Allerede flere dage før Litvinenkos død udtalte højtstående britiske kilder tæt på Udenrigsministeriet til The Times: "Vi taler ikke om 
en rutine spion-disput (med Rusland - TBL). Denne gang har vi at gøre med et mordforsøg på en udlænding i et andet land ved brug af metoder, som vi ved, at russerne i vid udstrækning behersker. Hvis vi finder noget substantielt, som kan forbinde dette med Moskva, vil det blive taget meget alvorligt. Dette er metoder, som normalt anvendes af terrorister."

\section{Sporene fører til Rusland}

Som bekendt fandt både det britiske og tyske politi i de efterfølgende uger og måneder mange tydelige po-210 spor. Og et utal af steder: På det formodede gerningssted, Millennium Hotel, hvor AL mødtes med tre russere den første november; på britiske og russiske fly tur/retur Moskva; i visumafdelingen på den britiske ambassade i Moskva og på et engelsk fodboldstadion. Desuden på diverse lokaliteter i Hamborg og omegn, hvor en af de ovennævnte russere havde rejst og opholdt sig. Ved hjælp af yderligere teknisk dissekering af det dræbende po-210 har den britiske efterforskning kunnet føre sporet tilbage til Rusland. Sporet af det, der ifølge flere kilder "kun er muligt at fremstille på en statskontrolleret reaktor".

Kronologien i sporingen er afgørende for, hvem britisk politi mistænker. Po-210-sporene daterer sig nemlig tilbage til begyndelsen og midten af oktober 2006 - langt før det fa- møse 'forgiftningsmøde' i London den første november mellem Litvinenko og de tre russere: Andrej Lugovoj og Aleksandr Kovtun, der begge ligeledes er forhenværende KGB/FSB-officerer, samt Vjatjeslav Sokolenko.

Det kan med stor sikkerhed fastslås, at de radioaktive spor forekommer et utal af steder i ugerne før den første november, hvor Litvinenko drak den giftige te.

Busbilletten, som AL anvendte på vej til det skæbnesvangre møde, var derimod helt uden po-210 spor. Den samme mangel på po-210 sporing forud for første november gælder AL's italienske kontaktperson, Mario Scaramella, der overbragte Litvinenko udskrifter af mails med angivelige 'dødslister', hvor navnet på Scaramella selv, den myrdede journalist Anna Politkovskaja og Litvinenko optrådte.

Også den russiske oligark, Boris Beresovskij, der ligesom Litvinenko er flygtet til London, er fundet polonium-fri før denne dato. I modsætning til russeren Lugovoj, der i London ikke bare har haft kontakt med Litvinenko, men også med Beresovskij, på hvis kontor han allerede i midten af oktober afsatte stærke po-210 spor.

Så kronologien er selvsagt meget afgørende for indkredsningen af mulige og sandsynlige gerningsmænd og bagmænd. Det samme er imidlertid de stort set upåagtede russiske terrorlove, som blev vedtaget i sommeren 2006, og i britisk 
presse fik betegnelsen 'License to Kill Abroad', fordi de giver de russiske sikkerhedstjenester mandat til at operere på udenlandsk territorium. Men herom senere. Først lidt om Aleksandr Litvinenkos baggrund.

\section{Litvinenkos baggrund}

Litvinenkos løbebane er lang og kringlet. I mange år tjente han som loyal undersåt i flere af den gamle Sovjetunions mange brændpunkter, før han endte som en skånselsløs kritiker af Putins nuværende Rusland. Det er altså historien om en loyal KGB-mand, der udviklede sig til, hvad jeg vil betegne som en politisk dissident. Hans modstandere har til gengæld ikke tøvet med at kalde ham en 'troløs landsforræder'. I sidstnæunte ordvalg ligger muligvis årsagen til Litvinenkos sørgelige død.

Aleksandr Litvinenko blev født i 1962 i byen Voronezj. En stor del af hans familie havde efter hans eget udsagn militær baggrund. Hans far gjorde tjeneste som læge i det militære system. I 1980 startede AL som værnepligtig, hvorefter han steg i graderne. I 1985 blev han indrulleret som officer i tropperne under Indenrigsministeriet (MVD). Her startede hans karriere inden for det daværende KGB, hvor Litvinenko hovedsagelig var beskæftiget i afdelinger, der tog sig af organiseret kriminalitet og terrorisme. Litvinenko har således - i modsætning til, hvad medierne skriver - aldrig været spion i klassisk forstand, da han ikke har arbejdet i udlandet. Modsat en nok så bekendt anden KGB-ansat, Vladimir Putin, der 'virkede' i Dresden, DDR.

Litvinenkos arbejde med optrævling af økonomiske mafia-strukturer og senere de mange voldelige sider af Sovjetunionens opløsning, navnlig i Kaukasus og Centralasien, blev uvægerligt påvirket af, at hans land blev ændret fra Sovjetunionen til Rusland, og hans arbejdsgiver fra KGB over FSK til FSB. Det var under sin udstationering i brændpunkterne, at Litvinenko langsomt, men sikkert begyndte at sætte spørgsmålstegn ved efterretningstjenestens opfattelse af 'statens sikkerhed' samt dens valg af metoder til at opretholde denne sikkerhed for den krympede supermagt. Hans oplevelser under den første Tjetjenienskrig 1994$96 \mathrm{blev}$ et afgørende vendepunkt. "Jeg har oplevet soldater dø i mine arme" har han berettet med tilføjelsen: "Ikke én eneste gang i disse år fik vi nogensinde en ordentlig forklaring på, hvorfor vi var udsendt, og hvad vi skulle forsvare $i$ alle disse konfliktområder." I en portrætudsendelse fra 2004 udtalte han: "Jeg havde engang en 15-årig tjetjensk dreng i forhør. Da jeg spurgte ham hvorfor han ikke gik i skole, men i stedet sloges sammen med banditter svarede drengen, at hele hans klasse var ved fronten... Dét blev et afgørende vendepunkt for mig." 


\section{På kant med systemet}

Med disse krigsoplevelser i bagagen vendte Litvinenko hjem til Moskva for i de følgende år at fortsætte sit arbejde i forskellige FSB-afdelinger for oprulning af den stadigt mere omsiggribende økonomiske kriminalitet under Jeltsin. Det var den periode, hvor den russiske økonomi undergik chokterapi. Eller med $\mathrm{Fi}$ nancial Times'tidligere korrespondent, David Satters ord: "Aldrig har man på så få år bevidnet en så stor overførsel af statslig ejendom til private".

Litvinenkos næste moralske dilemma i statens tjeneste blev den ordre, som han i 1998 modtog om at myrde den føromtalte oligark Boris Beresovskij, der under Jeltsin var en af de mest indflydelsesrige personer i Kremls økonomiske og politiske magtelite.

Litvinenko nægtede at udføre ordren. Men derved blev det ikke. Han og et par af hans medarbejdere i FSB's syvende departement tog det helt uhørte skridt at træde offentligt frem året efter på en TV-dækket pressekonference, hvor de i fuld offentlighed redegjorde for de ulovlige ordrer om likvideringer.

Andre kilder, heriblandt flere af Litvinenkos tidligere kolleger, har dog senere hævdet, at Litvinenko i denne periode hele tiden var stærkt styret af Beresovskij, og at den omtalte pressekonference var en velplanlagt medieaktion rettet direkte mod Beresovskijs konkurrenter i Kremls indercirkler.

Hvorom alting er: Denne afsløring af hemmelige operationer, der tilsyneladende var iværksat højt oppe i systemet, bragte Litvinenko endnu tættere på det tiltænkte offer Beresovskij. Omvendt fik Litvinenkos åbenmundethed en gang for alle bragt ham på kollisionskurs med Kremls mange sikkerhedstjenester. Litvinenko blev i de næste måneder skiftevis arresteret, frikendt ved domstole, for blot igen at blive anholdt (i selve retssalen, lige efter frifindelsen) af maskerede FSB-agenter og ført bort til Lefortovos eller Butyrkas fængsler. I alt tilbragte AL ni måneder bag tremmer.

\section{Flugt og eksil}

Det var på denne baggrund af chikanerier, fængslinger og trusler, at Litvinenko sammen med sin kone og søn besluttede at flygte fra Rusland via Tyrkiet til England i efteråret 2000. Her fik familien politisk asyl i maj 2001. I England gik AL straks i gang med at etablere kontakter til eksilmiljøet af andre flygtede russere, ligesom han etablerede stærke forbindelser til de tjetjenske flygtningekredse, herunder til Maskhadov-regeringens forskellige repræsentanter i Europa, hvoraf den kendteste er Akhmed Zakajev.

Ligesom dobbeltagenten Oleg Gordijevskij og andre flygtninge fra de sovjetiske og russiske sikkerheds- 
strukturer stillede han sin viden og udsmuglede arkivmateriale til rådighed og var i det hele taget en flittig skribent i medierne. I lighed med andre afhoppede KGB/FSB-officerer blev han in absentia i Rusland idømt flerårige fængselsdomme. Samtidig påbegyndte han sammen med historikeren Jurij Felsjtinskij udarbejdelsen af sit hovedværk: Blowing up Russia - terror from within, der første gang udkom i 2001. Hovedparten af bogen blev i begyndelsen optrykt i faksimile i små oppositionsaviser som for eksempel Anna Politkovskajas Novaja Gazeta og forblev derfor ukendt for et større russisk publikum.

Snart blev bogen forbudt. Det var det første totalforbud gældende for hele Rusland siden Solsjenitsyns bandlyste værker. Enkelte forsøg på at smugle bogen ind i Rusland og foranstalte diskussionsmøder og filmfremvisninger endte flere gange i vold. Under et enkelt sådant 'samizdat'-møde, blev deltagerne overfaldet og gennemtævet af voldelige bander, formentlig fra Putins nydannede ungdomsorganisation Nasji. En af de overfaldne døde senere af sine kvæstelser.

\section{9-bomberne}

Litvinenkos og Felsjtinskijs værk drejede sig om, hvem der stod bag de blodige terrorbomber, der ramte beboelsesejendomme forskellige steder i Rusland i eftersommeren 1999.
Bomber, der kostede over 300 uskyldige civile livet, og som blev præludiet til den anden Tjetjenienskrig under Ruslands nye midlertidigt udpegede præsident, Vladimir Putin. Han havde få år forinden været en helt ukendt embedsmand i Skt. Petersborg, hvor han arbejdede for den dynamiske reformborgmester, Sobtjak, der havde headhuntet ham fra den russiske sikkerhedstjeneste.

Ja, selv efter Jeltsin hentede Putin til Moskva, var der få, som holdt øje med hans gøren og laden. Og ikke mange fæstnede sig ved, at det var i hans tid som chef for den russiske sikkerhedstjeneste FSB, at den nyudnævnte rigsadvokat Jurij Skuratov der havde lovet, at slå hårdt ned på korruptionen, selv i Kreml - blev skandaliseret. Skuratov blev pludselig filmet i en sexscene med to unge kvinder, og da billederne blev vist $\mathrm{i}$ TV i primetime var han med et knips gjort politisk ukampdygtig.

Men en ting var sådanne beskidte tricks. Noget helt andet var anklagen om, at bagmændene bag terrorbomberne mod den russiske befolkning skulle findes i landets egen sikkerhedstjeneste eller en af FSB's mange underafdelinger - med det formål at starte en ny krig i Tjetjenien. Litvinenkos hovedpåstand i bogen er således, at Putins og den nyudnævnte chef for FSB Patrusjevs udsagn om, at der var et klart tjetjensk spor i bombeattentaterne, var en bevidst falsificering: en statsløgn, fabrikeret til lejligheden. Det lød og ly- 
der den dag i dag stadig fantastisk. Og dog er det svært at affærdige påstanden, når man læser Litvinenkos udsmuglede og omfattende specialarkiver, inklusive de trykte og verificerede hemmelige ordrer fra FSB's mange mørke operationer i for eksempel Dagestan og Tjetjenien.

\section{Den mærkelige øvelse}

I Litvinenkos bog er det stærkeste indicium på FSB's indblanding 'terrorbomben, der ikke sprang', i byen Rjazan. Lokale borgere i en beboelsesejendom opdagede her tre personer, der anbragte sække i en kælder. Lokalt politi og bombeekspertise blev tilkaldt, kemiske prøver og tests blev gennemført og sprængstofprøver fastslog, at der var tale om hexogen, det samme sprængstof, som blev anvendt ved de forudgående eksplosioner. Men da det lokale politi i Rjazan fik opsnuset de tre gerningsmænd, viste det sig, at de kom fra FSB i Moskva.

Ruslands daværende indenrigsminister Rusjajlo nåede endda at holde en stor pressebriefing om den vellykkede afværgemanøvre, før chefen for FSB Patrusjev pludselig ændrede forklaring på TV og hævdede, at det hele have været en øvelse med henblik på at teste befolkningens årvågenhed.

Sagsakterne om ‘øvelsen' i Rjazan blev hemmeligstemplet i 75 år frem, og det har næppe heller mindsket hverken Litvinenkos, Felsjtinskijs el- ler den berørte lokalbefolknings mistanke.

En anden af Litvinenkos kolleger, juristen og den forhenværende officer i FSB Mikhail Trepasjkin, bidrog med andre markante vidneudsagn om de mystiske bomber. I den enestående dokumentarfilm Disbelief, der er forbudt i Rusland, redegør han for, hvorledes han i efteråret 1999 genkendte en af de hovedeftersøgte fra FSB's efterlysningsplakater. Omgående ringede han til chefen for FSB, Patrusjev for at fortælle, at den afbildede person var en 'pengehvidvasker' fra en russisk-tjetjensk mafiaorganisation i Moskva, som Trepasjkin allerede i 1995 havde undersøgt. Patrusjevs svar: "Ham rører du ikke, for han arbejder for os."

Trepasjkin er i dag fængslet, dømt for at have afsløret statshemmeligheder for ingen ringere end det britiske MI-5. Han står på Amnesty Internationals Skriv for Liv-kampagne, og har senest bragt sig selv i livsfare ved at udsmugle breve til Litvinenko og britisk politi, hvor han meddeler sin viden til brug for efterforskningen af giftattentatet mod Litvinenko. Trepasjkin virkede indtil sin fængsling som advokat for flere af ofrene for 1999-bomberne med krav om sagens genåbning. Det blev afvist.

Listen over personer, der omkom på mystisk vis, fortsatte efter Litvinenkos udgivelse af sin bog i 2001. Det fremtrædende medlem af Dumaen, Sergej Jusjenkov, blev myrdet i foråret 2003 under efterforskning 
af terrorbombardementerne i 1999. Duma-medlemmet og chefredaktøren på Novaja Gazeta, Jurij Sjtjekotjikhin, døde - officielt af en allergisk reaktion - i sommeren 2003. Alt tyder på giftmord. Allerede i september 2003 fortalte Anna Politkovskaja undertegnede i Oslo, at en uafhængig væusprøve tydede på Thallium eller en anden gift. Sjtjekotjikhins død mindede til forveksling om Litvinenkos: Hårtab, svigt af indre organer, sluttelig kollaps.

\section{Et mord i Qatar}

Allerede kort tid efter flugten til England i efteråret 2000 udtalte Litvinenko sin frygt for, at han ville blive stræbt efter livet af de russiske sikkerhedstjenester, selv i udlandet. Hans afhoppede kolleger såsom dobbeltagenten Oleg Gordijevskij og den forhenværende general i KGB Oleg Kalugin bestyrkede ham i denne frygt. Samme Kalugin afslørede sandheden om et andet spektakulært giftmord fra KGB's hånd, nemlig 'paraply-mordet' på den bulgarske forfatter og dissident Georgij Markov, der døde af ricin-forgiftning i London i 1978.

Men så langt skal man nu ikke tilbage i tid for at finde et eksempel på et mord på udenlandsk territorium, begået af de russiske sikkerhedstjenester. Man skal blot tilbage til den 13. februar 2004, til den lille arabiske stat Qatar og dens hovedstad Doha. På denne dag dræbte to russiske agenter ved hjælp af en bilbombe Zelimkhan Jandarbijev, der en kort overgang var Tjetjeniens præsident. Jandarbijev havde forladt Tjetjenien og spillede nu en efter alt at dømme relativt underordnet rolle. Nok havde Kreml sat ham i forbindelse med terroraktionen mod Dubrovka-teatret i oktober 2002, ligesom Kreml havde sortlistet Jandarbijev som fundraiser for en 'islamistisk pengeindsamling' i den arabiske verden, men han spillede ingen særlig rolle længere i den tjetjenske selvstændighedsbevægelse. Alligevel blev han bombedræbt.

Det officielle dementi, som den russiske udenrigs-efterretningstjeneste (SVR) udsendte ved den lejlighed fortjener opmærksomhed, da det i lange passager synes at være forfattet efter samme standardformular, som den dementi-erklæring fra SVR, som blev udsendt kort tid efter mordet på Litvinenko. Itar-Tass rapporterede den 13. februar 2004: "SVR har på ingen måde deltaget i lederen af de tjetjenske ekstremisters død (...)". Ifølge chefen for SVR's presseafdeling, General Boris Labusov "har hverken KGB eller SVR taget del i sådanne aktioner siden 1959, da Bogdan Stashynskij likviderede Stefan Bandera i Tyskland (...)"

Samtidig boltrede den russiske, Kreml-tro presse sig med henvisning til såkaldt meget velinformerede kilder i teorier om 'interne tjetjenske pengeopgør' som årsag til mordet 
på Jandarbijev. Det blev dog afsløret som det pure opspind, da to russiske agenter samt en diplomat blev arresteret. De to agenter blev efterfølgende dømt på livstid (for blot senere at bliver sendt tilbage til strafafsoning i Rusland.) Efterfølgende har det russiske fængselsvæsen meddelt, at de dømte desværre er forsvundet.

Mordet på Jandarbijev viste, at Kreml allerede i 2004 - lang tid før de nye vidtgående terrorloves vedtagelse - foretog likvideringer i udlandet. Et halvt år senere var den russiske ledelse da også mere klar i mælet, som da den russiske forsvarsminister Sergej Ivanov på et NATOtopmøde udtalte, at Rusland "forbeholder sig retten til at eliminere terroristerne og alle deres støtter, overalt i verden."

Den kendte russiske militæranalytiker Pavel Felgenhauer var ikke i tvivl om fortolkningen: "Det betyder, at de sikkert vil prøve at myrde for eksempel en mand som Akhmed Zakajev i London”. I sommeren 2006 blev retorikken omsat til lovgivning, da en russisk terrorpakke udvidede de russiske sikkerhedstjenesters beføjelser til likvideringer betydeligt. De nye love blev temmelig oversete eller forblev ukommenterede fra vestligt officielt hold. Derimod blev de bemærket i eksilkredsene. Som den fremtrædende dissident Vladimir Bukovskij sagde i et interview til Weekendavisens udsendte, Ole Nyeng. i december 2006: "Der er én ting, I helt har overset i
Vesten: To love som Putin lod den russiske Duma vedtage i juli. Den første lov giver regimet mulighed for at bruge særlige dødspatruljer til likvidering af 'samfundsfjender' også uden for russisk territorium. Den anden lov udvider definitionen af, hvem der er samfundsfjende det er nu en meget bred definition, som blandt andet omfatter folk, der ydmyger den nationale værdighed og lignende sludder. Forsvarsministeren, Sergej Ivanov, kom endda ved den lejlighed med den interessante udtalelse, at en liste over mål allerede var udarbejdet. På et seminar i Washington den 19. januar støttede flere fremtrædende deltagere Bukovskijs udlægning, herunder den tidligere CIA-direktør James Woolsley.

\section{Andre mordteorier}

Nuvel - jeg har gennemgående valgt at opbygge denne gennemgang med udgangspunkt i den britiske efterforsknings teori om de russiske statsstrukturers indblanding i mordet på Litvinenko. Men naturligvis har der også været helt andre bud på gerningsmænd og motiver til giftattentatet. En teori har gået på, at Litvinenko blev myrdet på grund af sin 'italienske forbindelse'.

Både Litvinenko og hans kontaktmand Scaramella, som Litvinenko mødtes med den dag, han blev forgiftet, kunne formodes at samle sprængfarlig viden om de vedhol- 
dende anklager om en KGB-mafiaforbindelse i Italien. Altså anklagerne om, at italienske toppolitikere i årevis skulle være blevet betalt og dirigeret af KGB. Sagen er pågået i adskillinge år uden at Litvinenko har været involveret i den.

En anden teori er teorien om 'ukontrollable elementer'. Det har været hævdet, at morderne sagtens kunne være forhenværende russiske agenter, som handlede på egen hånd, drevet af personlige hævnmotiver eller pekuniære interesser. Den samme teori blev fremsat i forbindelse med mordet på Anna Politkovskaja, ligesom den er i forbindelse med alle andre mord, hvor et politisk motiv synes nærliggende. Man bedes dog her bemærke, at samtlige disse mord har rettet sig mod Kremlkritikere, hvilket er ganske sigende.

En tredje teori går på, at mordet blev begået af nogle af Litvinenkos egne politiske venner - fra Beresovskij til hans tjetjenske forbindelser. Formålet skulle være at sætte Putin og Rusland i et dårligt lys og fyre op under koldkrigsretorikken. Visse journalister og kommentatorer har fremført, at Putin og Kreml helt savner motiver, i modsætning til visse af Putin-kritikerne i eksil, der er kendt for deres egne blakkede metoder.

Visse amerikanske politiske kredse retter brodden mod Bush og de neokonservative, og anskuer mordet som et 'destabiliseringsforsøg' med det formål at mindske Putins vægt i international politik, for eksempel i Iran-tvisten og i Mellemøstspørgsmål generelt. Nogle russiske kommentatorer siger, at det er CIA, der står bag mordet.

Det britiske politi mener at kunne spore giften til bestemte, statslige reaktorlokaliteter, ligesom de konkrete spor er afsat af tre navngivne personer, hvilket i mine øjne i høj grad tager luften ud af også disse mere 'storpolitiske' motivanalyser. Teorierne stemmer ikke overens med efterforskningens resultater.

Jeg lader derfor afslutningsvis denne ekstraordinære mand - der selv gik fra at være statens tro tjener til at være en fuldblodsdissident få de afsluttende ord. Da jeg selv mødte Litvinenko i København i november 2003, hvor han sammen med Anna Politkovskaja deltog i et panelmøde, udtrykte han et stort håb om at hans bog måtte komme til flere menneskers kendskab: "I tror nok, at det jeg skriver og siger lyder for fantastisk til tider, men tro mig, jeg kender mentaliteten og tankegangen i systemet, og det er vigtigt at folk forstår dette."

Thomas Bindesbøll Larsen er historiker og formand for Støttekomiteen for Tjetjenien. 